\title{
STUDY OF THE EFFECT OF TEMPERATURE ON THE HARDNESS, GRAIN SIZE, AND YIELD IN ELECTRODEPOSITION OF CHROMIUM ON 1045 STEEL
}

\author{
SALVADOR BARBATO $R^{* 1}$, JILBERTO PONCE $F^{* 1}$, MARCELO JARA L ${ }^{1}$, JACQUELINE CUEVAS $S^{l}$ AND \\ RODRIGO EGAÑA $A^{2}$.
}

\author{
${ }^{l}$ Departamento de Química, Facultad de Ciencias Básicas, Universidad de Antofagasta, Casilla 170, Antofagasta Chile. \\ ${ }^{2}$ Christensen Chile S.A. Division UHCO, Antofagasta. \\ (Received: 8 March 2007 - Accepted: 11 January 2008)
}

\begin{abstract}
A study was made on the effect of temperature on the electrodeposition of hard chromium on 1045 steel within a range of $30^{\circ}$ to $60^{\circ} \mathrm{C}$., as shown by variations in reaction yield, surface hardness, and depositional grain size. Increase in temperature produced a decrease in faradic yield of the reaction of between $17 \%$ and $9 \%$, an increase in hardness from 550 to 700 Brinelli, and a decrease in deposited chromium grain size from 278 to $32.4 \mu \mathrm{m}$. The most notable effect of temperature difference was observed between $30^{\circ}$ and $40^{\circ} \mathrm{C}$. Chrono-potentiometric and potentiodinamic linear sweep were measured at $30^{\circ} \mathrm{C}, 40^{\circ} \mathrm{C}$ and $50{ }^{\circ} \mathrm{C}$ in an attempt to explain this behavior. The results obtained suggested the formation of a compact film typical of a nucleation process in chromium electrodeposition. An increase in temperature affects the formation of this film, decreasing its thickness and distributing it in a more homogeneous manner over the steel, as shown by a decrease in the grain size of the chrome deposited.
\end{abstract}

Keywords: electroplating, hard chromium, hardness, grain size, reaction yield chrono potentiometric and potentiodinamic linear sweep.

\section{INTRODUCTION}

The technology for plating metal components with hard chromium is important in industrial practice, including pieces such as valves, pistons, piston rings, hydraulic components and many other parts which are subjected to high degrees of wear or to a highly corrosive working environment. Chromeplated surfaces show good resistance to corrosion, low frictional coefficients, increased hardness, and good esthetic appearance ${ }^{1-3}$. Components of electroplating baths such as chromic acid are serious environmental pollutants and are dangerous to human health, based on their carcinogenic properties. This risk is related mainly to the high working temperatures of the process $\left(\sim 60^{\circ} \mathrm{C}\right)$ which markedly increase the formation of acid mist in the working environment .

There have been few studies on the mechanism of the electrodeposition of chrome on different substrates, and there is no agreement on how the transformation of $\mathrm{Cr}^{+6}$ to $\mathrm{Cr}^{0}$ occurs, although there is agreement that the sulfate ion plays a fundamental role, interacting with a colloidal film facilitating the electrodeposition of the chromium. The composition of this film is not completely clear, nevertheless XPS measurements show the presence of $\mathrm{Cr}_{2} \mathrm{O}_{3}$, $\mathrm{CrO}_{2}$ and $\mathrm{SO}_{4}^{2-4,5}$.

The present study represents experimentation designed to evaluate specific effects on the chrome-electroplating of 1045 steel when lowering the working temperature of the process, in an effort to reduce environmental hazards of the process while at the same time obtaining acceptable results. Using electrochemical measurements, a concurrent attempt was made to evaluate the effect of temperature on the formation of the cathodic film which accompanies the electrodeposition of the chromium.

\section{EXPERIMENTAL}

The electroplating cell for chromium deposition was a rectangular glass tank with a styrofoam top, through which were inserted the cathode (working electrode) made of 1045 steel, and four lead electrodes, in a surface area ratio of 1 a 4

The current and potential were controlled by a power supply, the main characteristic of which was a $98 \%$ transformation of alternating to direct current, and a maximum current output of 10 Amperes. Acquisition of currentpotential data was carried out using a computer controlled interface. Both the thermostat and the working cell were maintained in a fume hood in order to protect the laboratory and investigators from noxious gases emitted in the process.

The aqueous working solutions used included $250 \mathrm{~g} / \mathrm{L} \mathrm{CrO}_{3}$ p.a Merck, and $2.5 \mathrm{~g} / \mathrm{L}$ concentrated $\mathrm{H}_{2} \mathrm{SO}_{4}$ p.a. ${ }^{6,7}$. Surface hardness measurements were made on chrome-plated 1045 steel using a model HLN-11A hardness tester. A JEOL model JSM 6360 LV scanning electron microscope (SEM) was used for observation of the chrome-plated steel surfaces. The current density employed in this study was $1 \mathrm{~A} \mathrm{in.}^{-2}$, as typically used in the hard-chrome plating industry ${ }^{6}$ . Experimental electroplating was carried out at different temperatures ranging from $30^{\circ} \mathrm{C}$ to $60^{\circ} \mathrm{C}$. with an average time period of $23 \mathrm{~h}$ per test.

A conventional three-electrode cell was used in the electrochemical experiments. Chronopotentiometric and potentiometric linear swep measurements were carried out using Voltalab 40 equipment. The working electrodes consisted of 1045 steel discs with an exposed area of $1 \mathrm{~cm}^{2}$. The test surfaces were mirror finished using emery papers and aluminum oxide powder paste. A platinum sheet was used as a counter-electrode. A saturated calomel electrode (SCE) was used as a reference electrode. A working solution was $\mathrm{CrO}_{3} 1 \mathrm{M}$ ( Aldrich Chem. Co) and $0.01 \mathrm{M} \mathrm{H}_{2} \mathrm{SO}_{4}$ ( Merck p.a).

\section{RESULTS AND DISCUSSION}

\section{Effect of temperature on the morphological characteristics}

Table 1 shows the effect of increasing the temperature of the plating process and the mass and thickness of the chromium deposited over a given time. The calculation of theoretical mass, equation (1), and the mass deposited in the electrolysis, allows obtaining the faradic yield of the chromium electrodeposition reaction.

Table 1.- Variation in the mass and thickness of chromium deposited as a function of temperature at a constant current density of $1.00 \mathrm{~A} / \mathrm{in}^{2}$.

\begin{tabular}{|c|c|c|c|c|c|}
\hline $\mathrm{T},{ }^{\circ} \mathrm{C}$ & $\begin{array}{c}\text { Electrode } \\
\text { area, in }{ }^{2}\end{array}$ & $\mathrm{t} 10^{-4}[\mathrm{~s}]$ & $\begin{array}{c}\text { mass of } \\
\text { Chromium } \\
\text { deposited } \\
{[\mathrm{g}]}\end{array}$ & $\begin{array}{c}\text { Working } \\
\text { potential } \\
{[\mathrm{V}]}\end{array}$ & $\begin{array}{c}\text { Thickness of Cr } \\
{\left[\text { in } 10^{3}\right]}\end{array}$ \\
\hline 30 & 8.164 & 8,219 & 10.36 & 11.2 & 10.50 \\
\hline 40 & 8.939 & 8,159 & 8.91 & 11.04 & 9.50 \\
\hline 50 & 8.588 & 8,183 & 7.77 & 10.91 & 7.00 \\
\hline 60 & 8.534 & 8,759 & 6.49 & 10.41 & 5.50 \\
\hline
\end{tabular}

$$
m_{\text {theoreticd }}=\frac{I \times t \times \bar{M}}{F \times n}
$$

$\mathrm{I}=$ Current intensity (A)

$\mathrm{t}=$ Time $(\mathrm{s})$.

$\bar{M}=$ Molar mass of Chromium.

$\mathrm{F}=$ Faraday's constant

$\mathrm{n}=$ number of moles of electrons interchanged.

The theoretical mass was determined assuming that the total electrical charge was used for reducing the $\mathrm{Cr}^{+6}$ to $\mathrm{Cr}^{0}$. The percentage of faradic yield was obtained using equation (2). 
$\%$ Faradic yield $=\frac{m_{\text {experimental }}}{m_{\text {theorical }}} \times 100$

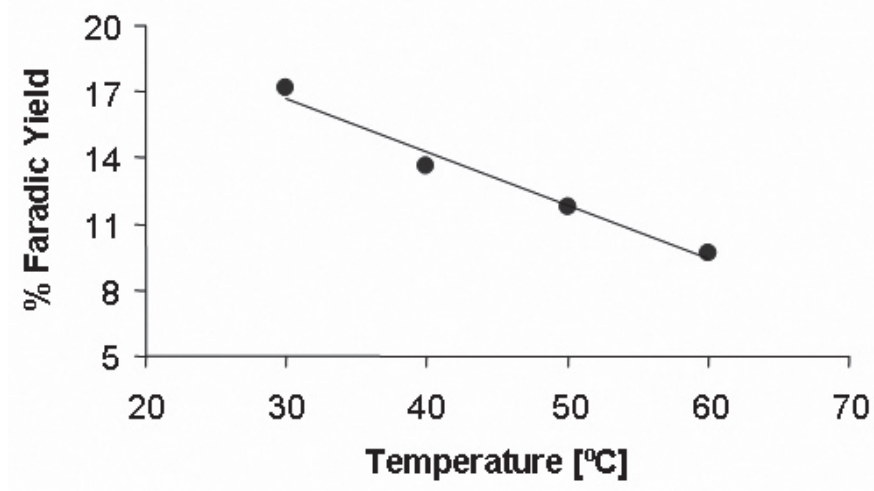

Fig. 1. Percent faradic yield of the electrodeposition reaction of hard chrome on 1045 steel as a function of temperature, normalized to one hour of electrolysis.

Fig. 1 shows that with an increase in temperature there is a decrease in the percentage faradic yield of the electrolytic reaction. Although not shown here, the decrease in faradic yield of the electrolytic reaction is accompanied by an increase in the release of hydrogen from the cathode. This behavior can be attributed to three factors: a) the speed of formation of $\mathrm{H}_{2}$ increases more rapidly than the electrodeposition of chromium with increase in temperature, and at the same time the cathodic efficiency decreases ${ }^{8} ; b$ ) The increase of the dissolution rate of the cathodic film with increase of the temperature and c) the decrease of over-potential hydrogen with the increase of the temperature produce an increase the $\mathrm{H}_{2}$ release reducing the thickness of the film cathodic Fig. 3 and Fig. 4.

Following photograph showed the 1045 steel test samples chrome plated at different temperatures and at a constant current density of $1\left[\mathrm{~A} \mathrm{in}^{-2}\right]$.

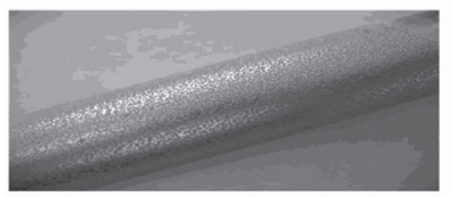

(A)

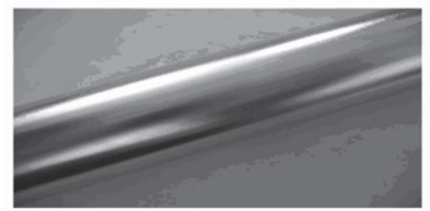

(C)

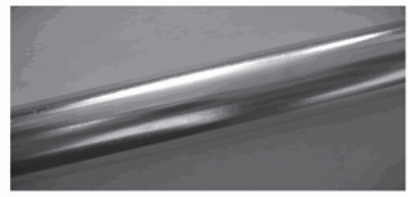

(B)

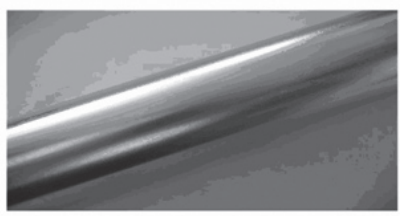

(D)
Photos A, B, C and D, bars of 1045 steel chrome-plated at $30^{\circ} \mathrm{C}, 40{ }^{\circ} \mathrm{C}$, $50{ }^{\circ} \mathrm{C}$ and $60^{\circ} \mathrm{C}$ respectively at a current density of de $1 \mathrm{~A} \mathrm{in}^{-2}$

These photos show, at the macroscopic level, that at $30^{\circ} \mathrm{C}(\mathrm{A})$ the chromium deposited is irregular and opaque; at increasing temperatures including, $40{ }^{\circ} \mathrm{C}$ (B), $50{ }^{\circ} \mathrm{C}$ (C) and $60{ }^{\circ} \mathrm{C}$ (D) the deposit becomes more homogeneous and bright. This observation shows the importance of temperature in the quality and uniformity of the chrome plating, which is confirmed by scanning electron microscope (SEM) study.
The SEM results (Photos E, F G and H, at 80x), show a decrease in deposited grain size of the chromium with increase in temperature, at the same time showing a more uniform and compact distribution of the grains, observed as surface rugosity. The most abrupt change in these effects was observed in the passage from $30^{\circ} \mathrm{C}$ to $40^{\circ} \mathrm{C}$. From $50^{\circ} \mathrm{C}$ to $60^{\circ} \mathrm{C}$, the distribution and grain size was very similar.

Table 2. Effect of temperature on the grain size of deposited chromium.

\begin{tabular}{|c|c|}
\hline Temperatura $\left[{ }^{\circ} \mathrm{C}\right]$ & Cr grain size, $[\mu \mathrm{m}]$ \\
\hline 30 & 278 \\
\hline 40 & 77.0 \\
\hline 50 & 32.4 \\
\hline 60 & 32.4 \\
\hline
\end{tabular}

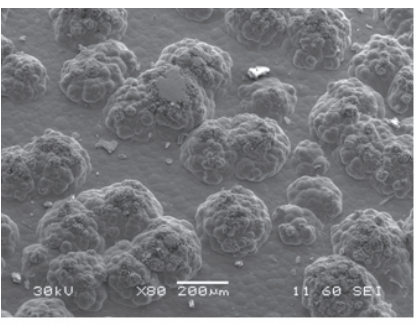

E

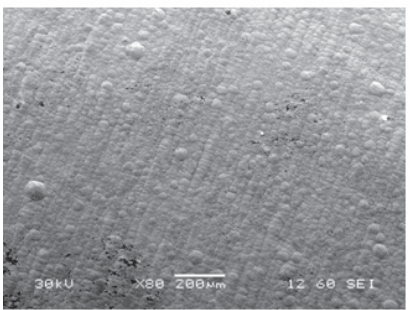

G

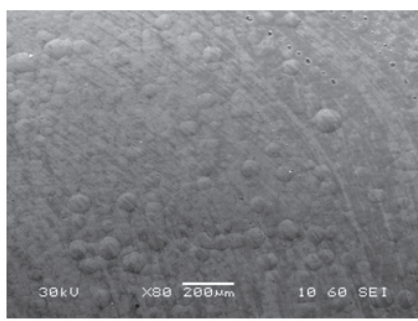

$\mathrm{F}$

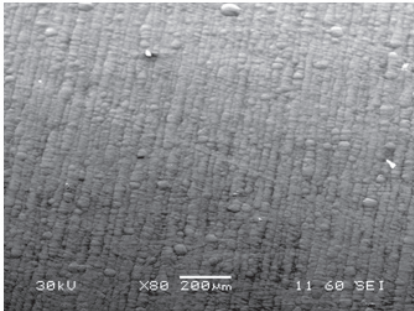

$\mathrm{H}$
SEM (80x) of the surface of 1045 steel chrome-plated at E: $30^{\circ} \mathrm{C}, \mathrm{F}$ : $40{ }^{\circ} \mathrm{C}, \mathrm{G}: 50{ }^{\circ} \mathrm{C}$ and $\mathrm{H}: 60^{\circ} \mathrm{C}$ using a current density of $1.0 \mathrm{~A} \mathrm{in}^{-2}$.

The hardness of the Chrome-plated surface (normalized to 0.01 in thickness) increases gradually with temperature (Fig. 2), which is supported by the SEM results. This behavior is explained by the progressive decrease in grain size of the chromium with increase in temperature, which produces greater homogeneity and compactness of the deposited grains.

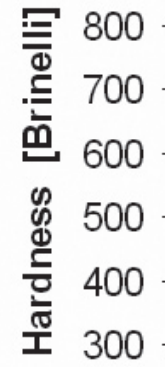

20
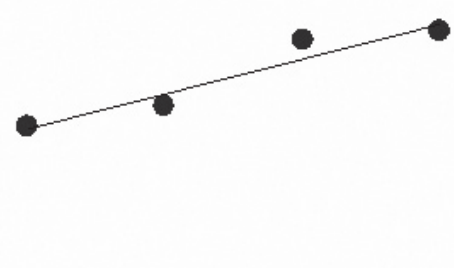

\section{0}

\section{Temperature $\left[{ }^{\circ} \mathrm{C}\right]$}

Fig. 2. Variation in surface hardness of deposited chromium normalized to 0.01 in thickness 
Electrochemical measurements

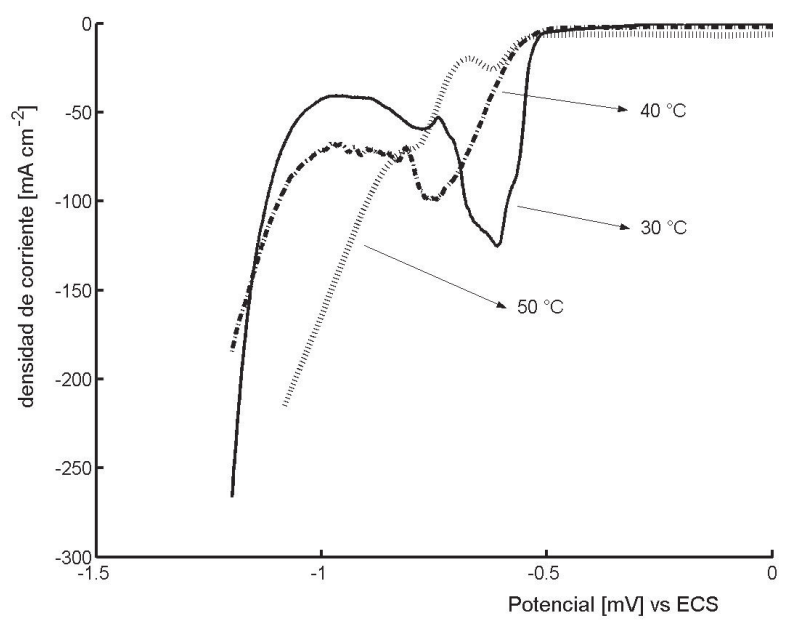

Fig. 3 j vs E potentiodinamic linear sweep curves; starting potential $640 \mathrm{mV}$ (open circuit potential), final potential $-1100 \mathrm{mV}$, step duration $5 \mathrm{~s}$, potential step $10 \mathrm{mV}$.

Fig. 3 shows the cathodic polarization curves in a $1 \mathrm{M}$ solution of $\mathrm{CrO}_{3}$ and $0.01 \mathrm{M} \mathrm{H}_{2} \mathrm{SO}_{4}$. The polarization curves can be divided into three zones. The first (A) is associated with the beginning of the formation of a cathodic film which, according to some authors, consists of a complex having a colloidal aspect, formed mainly by the trichromate ion $\left(\mathrm{HCr}_{3} \mathrm{O}_{10}{ }^{-}\right)$, where the chromate ions form a polymer by sharing corner oxygen atoms ${ }^{4}$. Zone (B) is where the release of hydrogen begins and stop when the formation of the cathodic film is complete. The third zone (C) is attributable to the reduction of the $\mathrm{Cr}^{6+}$ to $\mathrm{Cr}^{0}$, as well to the release of hydrogen; where $\mathrm{Cr}^{6+}$ and other species of chromium with less oxidation states are part of trichromate ion ${ }^{4,8-11}$. The trichromate ion is necessary by protection the $\mathrm{Cr}^{+3}$ ions, preventing the formation of a stable aquo complex. It is observed that the increase in temperature $\left(30{ }^{\circ} \mathrm{C}\right.$ to $\left.50{ }^{\circ} \mathrm{C}\right)$ has the effect of reducing the peak formed by zones (A) and (B) and increasing the current in zone $(\mathrm{C})$. This effect is quantified in Table 3 which shows the maximum potential $\left(\mathrm{E}_{\mathrm{p}}\right)$ and the coulomb charge consumed at the different temperatures. There is a decrease in the charge involved in the formation of the cathodic film with increase in temperature.

Table 3. The electric charge consumed in the peak formed by zones (A) and (B).

\begin{tabular}{|c|c|c|}
\hline $\mathrm{T}\left[{ }^{\circ} \mathrm{C}\right]$ & $\mathrm{Ep}[\mathrm{mV}]$ & $\mathrm{Q}\left[\mathrm{C} \mathrm{cm}^{-2}\right]$ \\
\hline 30 & -840 & 13,2 \\
\hline 40 & -830 & 9,51 \\
\hline 50 & --- & 4,0 \\
\hline
\end{tabular}

To better understand the effect of temperature on the formation of the cathodic film, chrono-potentiometric measurements were carried out by applying a cathodic current of $300 \mathrm{~mA} \mathrm{~cm}^{-2}$ for $0.5 \mathrm{~s}$ as shown in Fig. 4

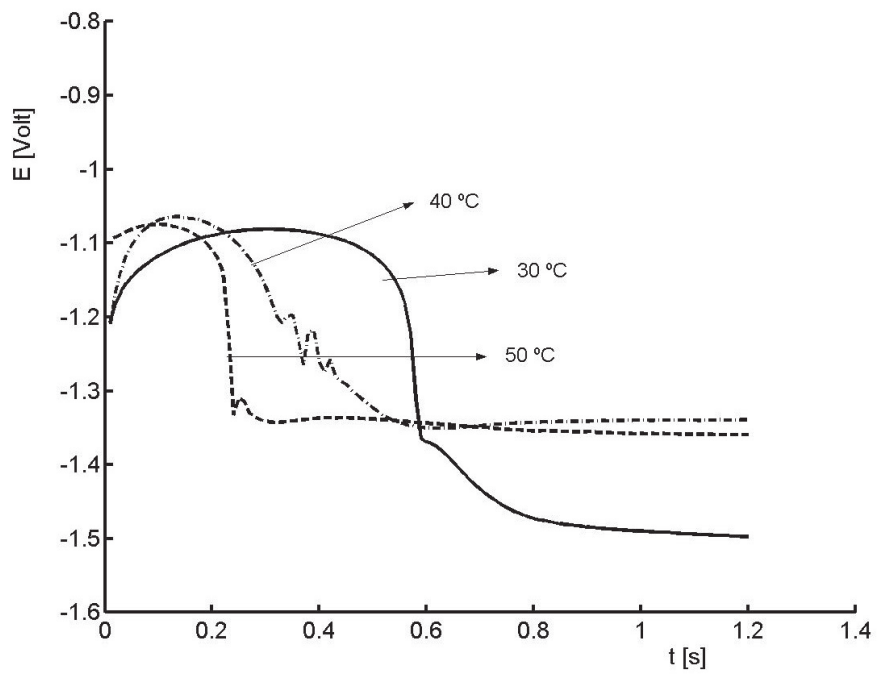

Fig. 4 Chronopotentiometríc measurements at temperatures of $30{ }^{\circ} \mathrm{C}, 40$ ${ }^{\circ} \mathrm{C}$ and $50{ }^{\circ} \mathrm{C}$. through the 1045 steel electrode in a solution of $1 \mathrm{M} \mathrm{CrO}_{3}$ and $0.01 \mathrm{M} \mathrm{H}_{2} \mathrm{SO}_{4}$.

This curve show that the potential was stabilized at $-1.1 \mathrm{~V}$ and later dropped abruptly to reach the potential for the emission of hydrogen; $-1.35 \mathrm{~V}$ at $40{ }^{\circ} \mathrm{C}$ and $50{ }^{\circ} \mathrm{C},-1.48 \mathrm{~V}$ at $30^{\circ} \mathrm{C}$. This behavior is typical of a nucleation process associated with the formation of a compact film ${ }^{8}$. It is observed that when increasing the temperature from $30{ }^{\circ} \mathrm{C}$ to $50{ }^{\circ} \mathrm{C}$ the area under the curve decreases, which may be due to a decrease in the formation of this film. To quantify this effect a determination was made on the thickness of the nucleation layer, based on electric charge consumed by the electrochemical process following equation (3).

$$
\tau=\frac{\bar{M} \times \int_{t_{i}}^{t_{f}} i \times d t}{F \times Z \times d}
$$

$$
\begin{aligned}
& \tau=\text { thickness }[\mathrm{cm}] \\
& \bar{M}=\text { molar mass }[\mathrm{g} / \mathrm{mol}] \\
& \mathrm{I}=\text { current densityt }[\mathrm{C} / \mathrm{s}] \\
& \mathrm{t}=\text { time } \\
& \mathrm{F}=96500 \mathrm{C} / \mathrm{mol} \\
& \mathrm{Z}=\text { oxidation number }(6+] \\
& \mathrm{d}=\text { density } \mathrm{Cr}=7,19 \mathrm{~g} / \mathrm{cm}^{3}
\end{aligned}
$$

Table 4. Thickness of the nucleation layer as a function of temperature.

\begin{tabular}{|c|c|}
\hline Temperature $\left[{ }^{\circ} \mathrm{C}\right]$ & Thickness $[\mu \mathrm{m}]$ \\
\hline 30 & 0.092 \\
\hline 40 & 0.0129 \\
\hline 50 & 0.0076 \\
\hline
\end{tabular}

The fact that the thickness of the cathodic film decreases with the increase in temperature can be attributed to a decrease in the viscosity of the cathodic film which promotes a more uniform distribution as well as a greater speed of dissolution. The chronopotentiometric measurements are in agreement with those presented by Okada and Yamamoto ${ }^{12}$, where the increase in the overpotential of hydrogen (Fig.3) is due to the increase in the thickness of the nucleation film, Table 4.

\section{CONCLUSIONS}

The present study of the effect of temperature on the electrodeposition of chromium on 1045 steel showed that the hardness increases while the grain size of the chromium deposited decreased with increase in temperature. Between 
$50^{\circ} \mathrm{C}$ and $60^{\circ} \mathrm{C}$ the results showed barely perceptible differences. This finding allows us to conclude that this electrochemical process could be carried out at $50^{\circ} \mathrm{C}$ without any important alterations in the resultant product, thus reducing the formation of acid mist typical at the higher temperature, with concomitant environmental benefits. Based on chronopotentiometric and potentiodinamic linear sweep measurements it is possible to establish that a potential of $-1.1 \mathrm{~V}$ would begin the nucleation process with the formation of an electrochemically active film which would influence both the grain size and the yield of the electrodeposition reaction of chrome in relation to the temperature. Increase in temperature provokes a decrease in the over- potential of hydrogen, favoring its release.

\section{ACKNOWLEDGMENTS}

Financial support from CORFO (Project FONTEC 204-3974) are gratefully acknowledged. The authors thank Christensen Chile S.A. Division UHCO, Antofagasta by donating bar of 1045 steel.

\section{REFERENCES}

1.- H. Silman, G. Isserlis, A. F. Averill, Protective and Decorative Coatings for Metals, Fisishing Publications, Teddington, 1987.

2.- R. Weiner, A. Walmsley, Chromiun Plating, Finishing Publications, Great Britain, 1980

3.- L. Fedrizzi, S. Rossi, R. Cristel, P.L. Bonora J. Electrochim. Acta. 49, 2803 (2004).

4.- J. P. Hoare, J. Electrochem. Soc. 126, 190 (1979).

5.- R. Giovanardi, E. Soragni, C. Fontanesi, V. De Renzi, U. Del Pennino, M.L. Foresti. J. Electroanal. Chem. 576, 243 (2005).

6.- P. Aitchinson. Austral. J. Appl.Sci. 1, 71(1950)

7.- M.A. LaBoda, A.H. Holden ang J.P. Hoare, J. Electrochem. Soc. 127, 1709 (1980).

8.- W.R.Rosas and A. Robin, J. Appl.Electrochem. 31, 531 (2001).

9.- J.C Saidington and G.R Hoey. J. Electrochem. Soc. 117, 1011 (1970).

10.- J.C Saidington and G.R Hoey. J. Electrochem. Soc. 120, 1475 (1973).

11.- D.F.Mitchell and M.J. Graham, J. Electrochem. Soc. 133, 936 (1986).

12.- H. Okada and K. Yamamoto, Electrochem. Technol. 6, 389 (1968). 